\title{
Cardiac Granular Cell Tumor
}

National Cancer Institute

\section{Source}

National Cancer Institute. Cardiac Granular Cell Tumor. NCI Thesaurus. Code C5360.

A very rare granular cell tumor that arises from the heart. 